\title{
OTRI7. DIAGNÓSTICO UNIVERSAL, OU PANDIAGNÓSTICO, DE TODOS OS PATÓGENOS HUMANOS POR PCR MULTIPLEX E SEQUENCIAMENTO MASSIVO PARALELO.
}

Fabricio K. Marchini ${ }^{1}$; Aline Castro Rodrigues ${ }^{2}$; Carla de Paula Lima ${ }^{2} ;$ Fabiana Poerner ${ }^{2}$; Lígia Cristina Kalb²; Luciano Luna²; Marco A. Krieger ${ }^{1}$.

${ }^{1}$ Fiocruz Paraná; Instituto de Biologia Molecular do Paraná (IBMP);

${ }^{2}$ Instituto de Biologia Molecular do Paraná (IBMP).

INTRODUÇÃO O espectro de doenças que acometem o homem, na sua maioria infecções respiratórias e entéricas, é responsável por considerável morbidade e mortalidade. Essas infecções são causadas por uma enorme variedade de microrganismos eucariotos, procariotos e virais. Com o desenvolvimento de métodos de diagnóstico molecular e sequenciamento de nova geração, é possível detectar e identificar de forma rápida e precisa esses agentes. Da mesma forma, a propagação desses microrganismos foi acentuada com as facilidades de deslocamento aéreo e a aglomeração de grande número de indivíduos provenientes de vários países em eventos internacionais.

OBJETIVO Diante deste panorama, o presente trabalho tem o objetivo de desenvolver um método universal de diagnóstico, ou pandiagnóstico, para detecção e identificação de todos os patógenos humanos conhecidos, para ser utilizado como ferramenta de vigilância epidemiológica durante grandes eventos internacionais.

METODOLOGIA O método baseia-se na amplificação por PCR em único tubo, e sequenciamento massivo paralelo, de sequencias específicas para cada patógeno humano, sendo eucarioto, procarioto e virus, presentes em diferentes tipos de amostras biológicas como sangue, secreções respiratórias, saliva, aspirado pulmonar, urina, fezes e líquor.

RESULTADOS Até o momento, foram desenhados 2575 primers para a detecção de 830 espécies (180 eucariotos, 248 procariotos e 402 vírus), compreendendo cerca de $95 \%$ de todos os patógenos humanos conhecidos, além do desenho de genes sintéticos para servirem de controle dos alvos nesta metodologia diagnóstica. 
CONCLUSÃO O desenvolvimento deste projeto permitirá a criação de uma central analítica de alta tecnologia e biossegurança para ser utilizada no diagnóstico de patógenos humanos em grandes eventos internacionais, como os Jogos Olímpicos e Copa do Mundo de Futebol.

PALAVRAS-CHAVE diagnóstico, ngs, doença infecciosa, pcr multiplex. 